\title{
The world status and population trends of the Great Bustard (Otis tarda): 2010 update
}

\author{
Juan C. ALONSO, Carlos PALACíN \\ Museo Nacional de Ciencias Naturales, CSIC, José Gutiérrez Abascal 2, 28006 Madrid, Spain
}

\begin{abstract}
The Great Bustard (Otis tarda) world population is estimated to be 44100-57000 individuals in 2010, of which about $57-70 \%$ occur in Spain, $15-25 \%$ in European Russia, $4-10 \%$ in China, Mongolia and south-eastern Russia, 3-4\% in Portugal, 3\% in Hungary, 1-2\% in Turkey, and smaller numbers in ten other countries. The reliability of current censuses and estimates may be described as high for a large fraction of the world population (67-75\%), and low for the remaining 25-33\% (including Russia, Mongolia, China, Turkey, Ukraine, Iran and Kazakhstan). In spite of continued declines reported for some countries (e.g., Turkey, Iran, China), the present survey suggests that total numbers have not significantly decreased worldwide during the last decade, as opposed to the globally declining trend currently assumed. This is due to a large fraction of the world total living in countries whose overall surveys are apparently stable (e.g., Spain, Portugal), after a noticeable recovery during the last few decades once the hunting ban was established. Only $6-10 \%$ of the world total is apparently still decreasing, mostly due to agricultural intensification, other causes of habitat degradation, and locally, also illegal hunting and collision with power lines. A small fraction of the world population (3-4\%), is clearly (Germany, Austria) or apparently (Hungary) increasing, due to management and conservation measures. Finally, 19-22\% of the world total has an uncertain status, due to inaccurate current or past censuses which prevent establishing reliable population trends. We recommend 1) keeping conservation efforts and the species' protection status worldwide, and 2) carrying out urgently nation-wide surveys in countries with low quality estimates, in order to confirm world numbers and trends.
\end{abstract}

Keywords Great Bustard (Otis tarda), population trends, status

\section{Introduction}

The first published assessments of the Great Bustard (Otis tarda) status estimated the world population to be around 20000-30000 birds during the final decades of the 20th century (Table 1 ). Most of them were based on numbers guessed or extrapolated from local counts, and thus the reliability of the total obtained strongly depended on the quality of the estimates made for the countries hosting the largest populations, particularly Spain, Russia and China.

Received 20 April 2010; accepted 16 May 2010

\footnotetext{
$\triangle$ Author for correspondence (Juan C. Alonso)

E-mail: jcalonso@mncn.csic.es
}

For example, the first detailed account of the Great Bustard numbers and distribution in Spain gave a total of about 17000-19000 birds in the 1990s (Alonso and Alonso, 1996), and suggested that all figures published before had underestimated the size of the Spanish population. Based on that study, the world estimates were increased by 6500 birds in only a couple of years (from 25640-30480, SEO/ BirdLife, 1997, to 31000-37000 birds, del Hoyo et al., 1996; BirdLife International, 2000a). A review of the species status in Spain made a few years later established a new total of about 23000 (Alonso et al., 2003), and a re-assessment of recent counts increased again the Spanish total to 27500-30000, and the world total to 43500-51200 birds (Palacín and Alonso, 2008). Since the progressive increase in 
Table 1 Published estimates of the world population of Great Bustards

\begin{tabular}{ll}
\hline Number of birds & \multicolumn{1}{c}{ Reference } \\
\hline ca. 20000 a & Collar, 1985 \\
$22480-23860^{\text {a }}$ & Hidalgo, 1990 \\
28000 & Collar, 1991 \\
$25640-30480$ & Hidalgo, 1997 \\
$31000-37000$ & BirdLife International, 2000a, 2007 \\
$43500-51200$ & Palacín and Alonso, 2008 \\
\hline
\end{tabular}

${ }^{a}$ These figures did not include the Asian populations of the eastern subspecies O.t. dybowskii.

Great Bustard numbers shown by these estimates is mostly due to a better knowledge of the species and the areas surveyed, any conclusions about population trends should be taken with care, and confirmed with more counts in the future.

Here we present an updated review of the Great Bustard status worldwide, based on the most recent counts available. We also discuss possible recent demographic trends in countries with adequate survey quality, and identify regions where more precise census work is urgently needed. Other details were given in our last population assessment (Palacín and Alonso, 2008), where we made a thorough review of the status and trends in each country of the species distribution range.

\section{Methods}

We revised all Great Bustard census results throughout the whole distribution range of the species, including papers published in scientific journals or presented at international meetings, as well as surveys accepted by national conservation authorities as reflecting the status of the species in their respective countries. The details of the census methodologies employed in each case may be found in the cited references. Besides, we also contacted most researchers working with Great Bustards to know their latest unpublished counts. To calculate the ponderated average year of estimate we used the last year of the time interval indicated under 'year of estimate' in Table 2, except for Spain, where we computed a ponderated average census year using the years of census for each region (the ponderated average for Spain was year 2007).

The following criteria were established to evaluate the quality of the population counts or estimates for each country: (a) high, when (a1) the estimate was based on counts at all or most Great Bustard areas within the country, carried out by observers with previous experience counting Great Bustards, and applying a systematic and standardized methodology (for more details see Alonso et al, 2003; Alonso et al, 2005a), including long series of yearly counts of well monitored populations (e.g., Germany, Hungary), and (a2) the interval between minimum and maximum estimates did not exceed $15 \%$ of the maximum estimate, with the exception of very small populations ( $<20$ individuals), in which case we qualified estimates as high quality even if they not fulfilled a1, and (a3) the counts are from recent years (usually within the last five years); (b) medium, when (b1) the estimate was based on surveys with incomplete coverage of the habitat potentially suitable, and (b2) the interval between minimum and maximum estimates was between $15 \%$ and $30 \%$ of the maximum estimate; and (c) low, when (c1) the estimate was based on extrapolations of census results at smaller areas, or series of records from several years, rather than on systematic, simultaneous counts, and (c2) the interval between minimum and maximum estimates was $>30 \%$ of the maximum estimate, and/or (c3) the estimates are not from very recent years.

\section{Results}

The world population of Great Bustards is currently estimated to be between 44054 and 57005 individuals (Table 2), of which the largest part (57-70\%) occurs in Spain. European Russia holds 15-25\% of the world total, north-western China (Xinjiang) 1-5\%, Mongolia, south-eastern Russia and north-eastern China 3-5\% (subspecies O. t. dybowskii), Portugal $3-4 \%$, Hungary $3 \%$, Turkey $1-2 \%$, and Ukraine $1-$ $2 \%$. Other countries hold less than $1 \%$ of the world total.

The reliability of current censuses and estimates may be described as high for the largest fraction of the world population (67-75\%, including the Iberian Peninsula, Hungary, Austria, Germany, and several central European countries with very small numbers), medium for Morocco, and low for a 25$33 \%$ (including Russia, Mongolia, China, Turkey, Ukraine, Iran and Kazakhstan) (Table 2). The ponderated average year of estimate was 2005 (Table 2).

\section{Discussion}

The world estimate of 44054-57005 Great Bustards 
presented here is a $1-11 \%$ higher than our previous estimate (43500-51200, Palacín and Alonso, 2008). However, the major part of this difference is most likely due to a better precision in population assessments for various European countries, and only a minor fraction may be attributable to a real increase in bird numbers. The accuracy of estimates for Russia, Turkey and some Asian countries is still low, and determine the large difference between minimum and maximum estimate intervals.

Spain and Portugal were the countries with high- est recent increases in population estimates (respectively, $7-14 \%$ in the last two years, and $35 \%$ in the last four years). Specifically for Spain, the main increases have been recorded in two provinces of region Castilla-La Mancha (290\% increase in 12 years in Cuenca, and $44-100 \%$ increase in 5 years in Toledo). According to our own unpublished data, such increases are not possible with the low reproductive rates typical of this species, and the best explanation is therefore a higher accuracy in the most recent censuses. Nevertheless, we know that some Spanish

Table 2 Current estimate of breeding populations of the great bustard, ordered by numbers of birds. See Methods for criteria used to evaluate the quality of estimate.

\begin{tabular}{|c|c|c|c|c|}
\hline & Min-Max & Reference & $\begin{array}{l}\text { Year of } \\
\text { estimate }\end{array}$ & $\begin{array}{l}\text { Quality of } \\
\text { estimate }\end{array}$ \\
\hline Spain & $29400-34300$ & Palacín and Alonso, 2008, updated $2010^{\mathrm{a}}$ & 2004-2010 & High \\
\hline European Russia & $8000-12000$ & $\begin{array}{l}\text { Malikov et al., 2000; Khrustov et al., 2003; } \\
\text { Antonchikov, 2006; Watzke et al., } 2007\end{array}$ & $1995-2005$ & Low \\
\hline NW China (Xinjiang) & $400-2400$ & $\begin{array}{l}\text { Gao et al., 2008; Wang et al., 2008; } \\
\text { Ying et al., } 2010\end{array}$ & 1990-2002 & Low \\
\hline $\begin{array}{l}\text { Mongolia + SE Russia } \\
+ \text { NE China }{ }^{\text {b }}\end{array}$ & $1500-2200$ & $\begin{array}{l}\text { Tian and Wang, 2001; Tseveenmyadag, } \\
\text { 2002; Goroshko, 2010; Kessler and } \\
\text { Tseveenmyadag, 2010; Tian, pers.com. }\end{array}$ & 1961-2002 & Low \\
\hline Portugal & 1893-1893 & Pinto and Rocha, 2010 (pers. com.) & 2009 & High \\
\hline Hungary & $1413-1582$ & Milós and Bankovics, 2010 (pers. com.) & 2009 & High \\
\hline Turkey & $400-1000$ & $\begin{array}{l}\text { Kiliç and Eken, 2004; Özbagdatli and Tavares, } \\
\text { 2006; Karakas and Akarsu, } 2009\end{array}$ & 1990-2008 & Low \\
\hline Ukraine & $520-680$ & $\begin{array}{l}\text { Yaremchenko and Bakhtiyarov, 2006; Dudkin } \\
\text { and Domashlinets, } 2008 \text { (pers. com.) }\end{array}$ & 2006 & Low \\
\hline Austria & $199-216$ & Raab, 2010 (pers. com.) & 2009 & High \\
\hline Iran & 89-161 & Amini, 2000 & 1990-1994 & Low \\
\hline Germany & 114-116 & Langgemach, 2010 (pers. com.) & 2009 & High \\
\hline Morocco & $91-108$ & Alonso et al., 2005b & 2005 & Medium \\
\hline Kazakhstan & $0-300$ & $\begin{array}{l}\text { National Academy of Sciences of Kazakhstan, } \\
\text { 1996; Kessler, } 2010\end{array}$ & 1990-1996 & Low \\
\hline Serbia and Montenegro & $35-36$ & Garovnikov, 2004 & 2004 & High \\
\hline Slovakia & $0-3$ & National report, $2008^{\mathrm{c}}$ & 2008 & High \\
\hline Czech Republic & $0-2$ & National report, $2008^{\mathrm{c}}$ & 2006-2007 & High \\
\hline Romania & $0-8$ & National report, $2008^{\mathrm{c}}$ & 2008 & High \\
\hline Moldova & 0 & BirdLife International, 2004b & 2004 & High \\
\hline Bulgaria & 0 & Deleriev et al., 2004 & 2004 & High \\
\hline Total & $44054-57005$ & & $2005^{d}$ & \\
\hline
\end{tabular}

${ }^{a}$ Includes references cited in Palacín and Alonso (2008), plus own surveys for several regions in 2009-2010, and pers. com. from Delegaciones Provinciales de Medio Ambiente of Toledo and Cuenca, Departamentos de Medio Ambiente of Aragón and Navarra.

b Subspecies Otis tarda dybowskii.

${ }^{\mathrm{c}}$ Communicated during the Second Meeting of the Great Bustard MoU held in Feodosia, Ukraine, in November 2008.

${ }^{d}$ Ponderated average census year, see Methods. 
and Portuguese populations have indeed increased slightly during the last 2-3 decades, particularly in Spain since a hunting ban was established in 1980, which stopped the steep decrease due to intensive hunting (up to 2000 birds/year, Trigo de Yarto, 1971) in previous decades. But many of these populations have now reached stability, and others have decreased or remained stable during the same period. Thus, the overall trend in Spain and Portugal might be best qualified as generally stable, with a slight tendency to increase at some high quality areas, and to decrease in marginal or worse conserved sites (Alonso et al., 2003, 2004; Pinto et al., 2005; Pinto and Rocha, 2006; Palacín and Alonso, 2008). Longer and more precise series of censuses are still necessary in both countries in order to determine whether there is still an intrinsic demographic increase, or the species is mostly stable.

A remarkable increase has also been recently observed in Austria (18-19\% in just three years, between 2006 and 2009), which might perhaps be explained by a combination of high breeding success of the Austrian bustards, and some dispersal from nearby Hungarian populations. More reasonable increases have been recorded in Hungary $(4-17 \%$ between 2006 and 2009) and Germany (4-5\% between 2007 and 2009). The recent increases in these three countries, where Great Bustards had declined during many decades through the 20th century, may be attributed to the habitat protection and other conservation measures (Raab, 2004, 2006; Bankovics et al., 2005; Langgemach and Bellenbaum, 2005; Langgemach and Liztbarski, 2005; Bankovics, 2006; Túzokvédelmi Program, 2006).

In other countries, surveys are incomplete and most of them already somewhat old. The current estimates for these countries are usually based on extrapolations of numbers counted in smaller regions to the whole areas guessed to include habitat suitable for the species. Because such estimates are subject to high potential errors, they are here considered of lower quality. Moreover, these estimates do not enable establishing reliable demographic trends, when compared to figures published in the past. Examples are Russia, Mongolia, China, Iran, Turkey, Ukraine, and Kazakhstan. Precise and extensive census work is still necessary in these countries, in order to ascertain numbers and demographic trends. Specifically for the subspecies $O$. tarda tarda in China, a recent revision suggested that Gao et al's (2008) estimate for Xinjiang region was based on relatively old observations made in 1992-1993, and should be considered an overestimation of current numbers (Ying et al., 2010). These authors propose that numbers have probably decreased during the last two decades in Xinjiang, to some $300-400$ birds (Ying et al., 2010). Given the huge size of this region, and in spite of the argued recent decrease, it could also be that detailed surveys conducted in the future result in higher numbers than these minimum estimates. Finally, numbers are relatively well known in Morocco and very accurate in several central European countries, where the species has recently gone extinct or is on the brink of extinction (Table 2).

In spite of the confounding effect of an increasing census accuracy through the last years, the comparison of the present review (Table 2) with previous world population estimates (see Table 1) strongly support our assertion that Great Bustard total numbers have not decreased worldwide, at least during the last two decades (Palacín and Alonso, 2008). This contradicts the global declining trend assumed until recent years (BirdLife International, 2004a, 2004b, 2007). The lack of a better knowledge of numbers and trends in several countries with important Great Bustard populations (e.g., Russia, Mongolia, China, Turkey, Ukraine) prevent us from drawing more precise conclusions about a worldwide demographic trend. In some of these countries the species is believed to be declining (e.g., China, see details for other countries in Palacín and Alonso, 2008), but the larger size of the Iberian population and its positive trend during the last years suggests that the world total might have remained more or less stable, or even slightly increased. These worldwide trends will only be completely confirmed when appropriate series of reliable counts become available in those countries where current estimates are still of low quality.

Acknowledgements We thank A. Antonchikov, A. Bankovics, A. Barati, O. Goroshko, J. Hellmich, T. Langgemach, I. Leszai, B. Litzsbarski, R. Karakas, A. Kessler, A. V. Khrustov, L. Milós, M. Ming, M.L. Oparin, O.S. Oparina, M. Pinto, R. Raab, P. Rocha, and X.H. Tian for the information on great bustards in their countries, and A. Wang for his help and Chinese translations during the International Symposium on Great Bustards in Beijing. We are also grateful to all people in Spain who provided us with valuable information on local populations, or worked with us during the surveys. Special thanks are given to M. Alcántara, J.A. Arranz, A. Balmori, M. Elósegui, J. Ezquerra, M. Guerrero, J. Larumbe, for survey data in several Spanish regions, and to C. Bravo, M. Magaña, C. Ponce, 
and A. Torres for collaborating in recent censuses. Funds to complete this study were provided by project CGL2008-02567 of the Dirección General de Investigación.

\section{References}

National Academy of Sciences of Kazakhstan. 1996. The Red Book of Kazakhstan. Vol.1. Animals. Part 1: Vertebrates. 3rd Edition. Institue of Zoology, National Academy of Sciences of Kazakhstan, Almaty.

Alonso JC, Alonso JA. 1996. The Great Bustard Otis tarda in Spain: present status, recent trends and evaluation of earlier censuses. Biol Conserv, 77:79-86.

Alonso JC, Martín CA, Alonso JA, Palacín C, Magaña M, Lane SJ. 2004. Distribution dynamics of a great bustard metapopulation throughout a decade: influence of conspecific attraction and recruitment. Biodivers Conserv, 13:1659 -2004 .

Alonso JC, Palacín C, Martín CA. 2003. Status and recent trends of the Great Bustard (Otis tarda) population in the Iberian Peninsula. Biol Conserv, 110:185-195.

Alonso JC, Palacín C, Martín CA. 2005a. La Avutarda Común en la Península Ibérica. Población actual y método de censo. SEO/BirdLife, Madrid. (in Spanish)

Alonso JC, Palacín C, Martín CA, Mouati N, Arhzaf ZL, Azizi D. 2005b. The Great Bustard Otis tarda in Morocco: a re-evaluation of its status based on recent survey results. Ardeola, 53:79-90.

Amini TH. 2000. The status of Great Bustard Otis tarda in Iran. Sandgrouse, 22:55-60.

Antonchikov A. 2006. Great and little Bustard in Russia: conservation problems and prospects. In: Leitao D, Jolivet C, Rodriguez M, Tavares J (eds) Bustard Conservation in Europe in the Last 15 Years. RSPB/BirdLife, Bedfordshire, pp 39-43.

Bankovics A. 2006. The situation of Great Bustard in Hungary. In: Leitao D, Jolivet C, Rodriguez M, Tavares J (eds) Bustard Conservation in Europe in the Last 15 Years. RSPB/BirdLife, Bedfordshire, pp 35-38.

Bankovics A, Boros E, Németh Á, Bíró C, Bankovics A. 2005. Reasons of the population increase of Great Bustard (Otis tarda) in the Kiskunság (Hungary). Aquila, 112:163-168.

BirdLife International. 2000a. Threatened Birds of the World. Lynx Edicions and BirdLife International, Barcelona-Cambridge.

BirdLife International. 2000b. European Bird Populations: Estimates and Trends. BirdLife Conservation Series No.10. BirdLife International, Cambridge.

BirdLife International. 2004a. Threatened Birds of the World 2004. CD-ROM. BirdLife International, Cambridge.

BirdLife International. 2004b. Birds in Europe: Population
Estimates, Trends and Conservation Status. BirdLife Conservation Series No.12. BirdLife International, Cambridge.

BirdLife International. 2007. Species factsheet: Otis tarda. http://www.birdlife.org. Accessed 30 May 2007.

Collar NJ. 1979. Bustard Group general report. ICBP Bull, XIII:129-134.

Collar NJ. 1985. The world status of the Great Bustard. Bustard Stud, 2:1-20.

del Hoyo J, Elliott A, Sargatal J. 1996. Handbook of the Birds of the World. Hoatzin to Auks. Vol. 3. Ediciones Lynx, Barcelona.

Deleriev S, Zehtindjiev P, Georgiev D. 2004. National report, Republic of Bulgaria. Memorandum of Understanding on the Conservation and Management of the Middle-European Population of the Great Bustard (Otis tarda). Convention on Migratory Species. Illmitz, Austria, 17-18 September. http://www.cms.int/species/otis_tarda/meetings/GB_1/Great _Bustard_1st_SS_Meeting.htm. Accessed 11 July 2007.

Gao X, Yang W, Qiao J, Yao J, Xu K. 2008. Distribution and status of bustards in China. Front Biol China, 3:385-391.

Garovnikov B. 2004. A brief report about protection of Great Bustard in Serbia and Montenegro. Memorandum of Understanding on the Conservation and Management of the Middle-European Population of the Great Bustard (Otis tarda). Convention on Migratory Species. Illmitz, Austria, 17-18 September. http://www.cms.int/species/otis_tarda/ meetings/GB_1/Great_Bustard_1st_SS_Meeting.htm. Accessed 11 July 2007.

Goroshko OA. 2010. Present status of population of Great Bustard (Otis tarda dybowskii) in Dauria and other breeding grounds in Russia and Mongolia: distribution, number and dynamics of population, threats, conservation. First International Symposium on Conservation of Great Bustard. Beijing, 10-11 April.

Hidalgo SJ. 1990. World status of the Great Bustard (Otis $\operatorname{tarda}$ ) with special attention to the Iberian peninsula populations. Miscelanea Zool, 14:167-180.

Hidalgo SJ. 1997. Avutarda Común Otis tarda. In: Atlas de la Aves de España (1975-1995), Lynx Edicions, Barcelona, pp 170-171. SEO.

Karakas R, Akarsu F. 2009. Recent status and distribution of the Great Bustard, Otis tarda, in Turkey. Zool Middle East, 48:25-34.

Kessler A. 2010. Great Bustard (Otis tarda) in Central Asia: Research. http://www.public.asu.edu/aekessle/research. html. Accessed 10 June 2010.

Kessler A, Tseveenmyadag N. 2010. Asian Great Bustard in northern central Mongolia: habitat and migration route. First International Symposium on Conservation of Great Bustard, Beijing, 10-11 April.

Khrustov AV, Shlyakhtin GV, Tabachishin VG, Zavialov EV. 
2003. Habitats and modern status of the Great Bustard (Otis tarda) population in the European Russia. The Bustards in Russia and adjacent countries, 2:98-107. Saratov University Press, Saratov.

Kiliç DT, Eken G. 2004. Türkiyenin Önemli kus Alanlari 2004 Gúncellemesi. Doga Dernegi, Ankara.

Kovshar A, Bekenov AB, Dukravetz GM. 1996. The Red Data Book of Kazakhstan. Vol. 1. Animals. Part 1: Vertebrates. 3rd Edition. Institute of Zoology, National Academy of Sciences, Almaty, Kazakhstan.

Langgemach T, Bellebaum J. 2005. Predation and the conservation of ground-breeding birds in Germany. Vogelwelt, 126:259- 298.

Langgemach T, Litzbarski H. 2005. Results of artificial breeding in the German Great Bustard (Otis tarda) conservation project. Aquila, 112:191-202.

Malikov AN, Khrustov AV, Shlyakhtin GV, Zavyalov EV, Tabachishin VG. 2000. Current status and conservation prospects for the Great Bustard (Otis tarda L.) population in the Eastern Europe. The Bustards in Russia and Adjacent Countries, 1:47-57. Saratov University Publisher, Saratov.

Özbagdatli N, Tavares JP. 2006. The situation of Great and little Bustards in Turkey. In: Leitao D, Jolivet C, Rodriguez M, Tavares J (eds) Bustard Conservation in Europe in the Last 15 Years. RSPB/BirdLife, Bedfordshire, pp 45-49.

Palacín C, Alonso JC. 2008. An updated estimate of the world status and population trends of the Great Bustard Otis tarda. Ardeola, 55:13-25

Pinto M, Rocha P. 2006. The situation of Great Bustard in Portugal. In: Leitao D, Jolivet C, Rodriguez M, Tavares J (eds) Bustard Conservation in Europe in the Last 15 Years. RSPB/BirdLife, Bedfordshire, pp 27-30.

Pinto M, Rocha P, Moreira F. 2005. Long-trends in great bustard (Otis tarda) populations in Portugal suggest concentration in single high quality area. Biol Conserv, 124:415-423.

Raab R. 2004. Austrian national report. Memorandum of Understanding on the Conservation and Managenment of the
Middle-European Population of the Great Bustard. (Otis tarda). Illmitz, Austria, 17-18 September. Convention on Migratory Species. http://www.cms.int/species/otis tarda/ meetings/GB_1/Great_Bustard_1st_SS_Meeting.htm. Accessed 11 July 2007.

Raab R. 2006. Zur situation der Großtrappe. Weidwerk, 4:1214.

SEO/BirdLife. 1997. Atlas de las Aves de España 1975-95. Lynx Edicions, Barcelona.

Tian XH, Wang JJ. 2001. Chinese Great Bustard. Northeast Forestry University Press, Harbin, pp 98-107.

Tseveenmyadag N. 2002. Great bustard (Otis tarda dybowskii L.) in Mongolia. Ornithological Laboratory, Institute of Biology, Mongolia Acad Sciences. unpublished report.

Trigo de Yarto E. 1971. La avutarda en España. XVIII Triennial General Meeting of the International Council for Hunting. Federación Española de Caza, Madrid. unpublished report.

Túzokvédelmi Program. 2006. Több mint 1300 túzok van Magyarországon. http://www.tuzok.hu/index.php?p=newsa ndnyelv=hunandid=2. Accessed 11 July 2007.

Watzke H, Oparin ML, Kondrantekov IA, Oparina OS. 2007. The great Bustard population density in the Saratov district east of the river Volga - results of censuses in autumn 1998, 1999 and 2000. Bustard Stud, 6:65-74.

Wang Q, Ming M, Gao Y. 2006. Fauna Sinica. Aves Vol. 5, Gruiformes, Charadriiiformes and Lariformes. Science Press, Beijing, pp 129-143. (in Chinese)

Yaremchenko O, Bakhtiyarov O. 2006. Great Bustard (Otis tarda) in Ukraine: history, current, status, conservation problems and strategies. In: Leitao D, Jolivet C, Rodriguez M, Tavares J (eds) Bustard Conservation in Europe in the Last 15 Years. RSPB/BirdLife, Bedfordshire, pp 145-149.

Ying C, Ming M, Peng D, Baowen H. 2010. Survival status of Great Bustard Otis tarda tarda in Xinjiang, the west of China. First International Symposium on Conservation of Great Bustard, Beijing, 10-11 April.

\title{
全球大铇的现状及种群发展趋势
}

\author{
Juan C. ALONSO, Carlos PALACÍN
}

(Museo Nacional de Ciencias Naturales, CSIC, José Gutiérrez Abascal 2, 28006 Madrid, Spain)

摘要：2010年大鸨的全球种群数量估计为44100-57000 只，其中57-70\%分布于西班牙，俄罗斯的欧洲 部分占 $15-25 \%$, 中国、蒙古及俄罗斯东南部共占 $4-10 \%$, 葡萄牙占3-4\%, 匈牙利占 $3 \%$, 土耳其占 $1-$ $2 \%$, 其余零星分布于其他 10 个国家。在这次估算和调查结果中, 大部分统计数据（占全球种群数量 
的 67-75\% ) 的可靠性很高, 其余25-33\%（分布于俄罗斯、蒙古国、中国、土耳其、乌克兰、伊朗、 哈萨克斯坦等国家) 或因调查不完善或因数据陈旧导致可靠性较低。虽然有报道称部分国家 (如土耳 其、伊朗和中国) 的大铇种群数量持续下降, 但本次调查表明, 在过去的 10 年里, 全球种群数量并 没有明显减少, 与目前有关全球种群数量呈下降趋势的预测恰恰相反。这是由于近些年在大铇主要分 布区 (如西班牙、葡萄牙) 开展了全面、稳定的调查, 使结果更准确; 且在这些国家制定禁捕令后的 几十年里, 大鸨数量有明显恢复。仅在生活着全球大鸨总数的 $6-10 \%$ 的地区, 种群数量仍存在明显下 降的现象, 这主要是由于农业活动加剧以及栖息地退化、非法捕猎、触碰高压线等原因造成的。只有 极少部分 (占全球种群数量的 3-4\%) 因管理和保护措施得当, 种群数量有明显的（德国、奥地利） 或显著的 (匈牙利) 增加。占全球总数的 $19-22 \%$ 因当前或过去的调查不准确, 现状和种群发展趋势 不明确。因此, 我们建议：1）继续保护该物种以及对全球现状的关注；2）为更准确地估算大铇全球 数量和趋势, 应在种群资料相对缺乏的国家尽快展开全国性的调查。

关键词: 大铇 (Otis tarda), 种群趋势, 现状 